\title{
New evidences of microbial mineralization in botryoidal dolostones, Upper Ediacaran Dengying Formation, Sichuan Basin
}

\author{
XiUfEN ZHAI ${ }^{1}$, PING LUO ${ }^{2}$, ZHIDONG GU ${ }^{3}$, HUA JiANG ${ }^{4}$, \\ TONGSHAN WANG ${ }^{5}$ \\ ${ }^{1}$ RIPED, CNPC, zhaixiufen@petrochina.com.cn \\ ${ }^{2}$ RIPED, CNPC, pluo@petrochina.com.cn \\ ${ }^{3}$ RIPED, CNPC, guzhidong@petrochina.com.cn \\ ${ }^{4}$ RIPED, CNPC, jianghua2009@petrochina.com.cn \\ ${ }^{5}$ RIPED, CNPC, wts2007@petrochina.com.cn
}

Botryoidal dolostones are widespread in the Second Member of the Upper Ediacaran Dengying Formation in the Yangtze Platform, and they are unique. Although they are important host rocks for giant gas reservoirs, and have been extensively discussed, there is no agreement on their origin, particularly with regard to microbial impact on mineralization processes in botryoidal laminations. In this paper, typical botryoidal laminations were studied under Polarized Optical Microscopes, a Scanning Electron Microscope (SEM) and an Energy Dispersive Spectrometer (EDS) to investigate their origins. Three botryoidal lamination types - sedimentary stratiform lamination, karst lining lamination, and spherical encrusting lamination - were distinguished, depending on macroscopic morphology, with scales ranging from millimeters to centimeters. All of these three lamination types are composed of fibrous and bladed crystals growing perpendicularly to botryoidal laminae, which have hitherto been implicitly considered to be the results of abiogenic chemical precipitation. Abundant new microbial evidence was found in fibrous and bladed crystal layers, consisting of dark layers and bright layers. In dark layers, euhedral dolomite rhombs were observed suspended around linear and tubular filaments, or wrapped in sheet extracellular polymeric substances (EPS), and the dolomite size mainly ranged from $<1$ micron to 5 microns. In bright layers, coarser sparry dolomites were observed, connected by radial sheaths and trychomes, and the dolomite size was mainly around 10 microns. Different species of bacteria, which are closely related to the macroscopic morphology of laminations, were observed in both bright and dark layers. The results are useful in understanding the formation mechanism of the Neoproterozoic botryoidal dolostones by documenting abundant evidence of microbial activity. The results may also provide insights into the occurrence and evolution of life in the Pre-Cambrian era. 